\title{
DIFFERENCE IN EFFECTIVENESS OF WARM GINGER WATER COMPRESS AND SOUR TURMERIC ON REDUCING PRIMARY MENSTRUAL PAIN IN MIDWIFERY STUDENTS AT MARANATHA SCHOOL KUPANG, EAST NUSA TENGGARA
}

\author{
Matilda Bupu Ria, Clara Yunita Ina Ola, Damita Palalangan \\ Study Program of Diploma-III in Midwifery, Institute of Health \\ Science Maranatha Kupang, East Nusa Tenggara
}

\begin{abstract}
Background: Dysmenorrhea is pain during menstruation felt by adolescent women, usually felt with cramps and concentrated in the lower abdomen. Complaints of menstrual pain can vary, ranging from mild to severe. This study aimed to prove the difference between the effectiveness of warm ginger water compress and the consumption of sour turmeric on reducing primary menstrual pain in students of Study Program of Diploma-III in Midwifery, Institute of Health Science Maranatha, Kupang, East Nusa Tenggara.

Subjects and Method: This was a quasi-experiment conducted at Maranatha school, Kupang, East Nusa Tenggara, in 2019. A sample of 60 female students with menstrual pain was divided into two groups: (1) 30 students in the experimental group received warm ginger compresses, and (2) 30 students in the control group received turmeric and sour drinks. The dependent variable was menstrual pain, which was measured by visual analog scale (VAS). The independent variable was dysmenorrhea pain reliever herbal medicine (either warm compresses of ginger or tamarind turmeric). The data were analyzed by Mann-Whitney test.

Result: Mean pain score in tamarind turmeric drink group (Mean= 27.32; $\mathrm{SD}=1.38$ ) was lower than the mean pain score in the ginger warm compresses (Mean $=33.68$; SD $=1.38)$, and it was statistically significant $(\mathrm{p}=0.148)$.

Conclusion: Tamarind turmeric drink is more effective than the ginger warm compresses in relieving dysmenorrhea.

Keyword: Primary Menstrual Pain, Warm Ginger Compress, Consumption of Turmeric and Acid.

Correspondence:

Matilda Bupu Ria. Study Program of Diploma-III in Midwifery, Institute of Health Science Maranatha, Kupang, East Nusa Tenggara. Jl. Kamp. Bajawa Nasipanaf, Kupang district, East Nusa Tenggara. Telp/Fax: 0380-8552971. E-mail: matildabupuria19@gmail.com. Mobile +6281241254153
\end{abstract}

The 7th International Conference on Public Health Solo, Indonesia, November 18-19, 2020 | 215 https://doi.org/10.26911/the7thicph.03.35 